\title{
Er eldrebølgen på vei inn i sykehusene?
}

Flere prognoser tilsier økt behov for sykehustjenester i tiden fremover. Dette tilskrives i første rekke den medisinske utvikling, med stadig flere og bedre tilbud om behandling for befolkningen generelt. Dessuten kommer eldrebølgen - den store etterkrigsgenerasjonen trer etter hvert inn i pensjonistenes rekker, og de som blir eldre, lever stadig lenger. Det er godt dokumentert at eldre trenger mer ressurser fra helsevesenet. Økt behov for intensivbehandling ser man allerede $i$ aldersgruppen ned til 60 år, og her forventer man en ytterligere økning i behandlingsbehovet på ca. 30\% i løpet av de neste 10-15 årene (1). Sommerli \& Nielsens artikkel i dette nummer av Tidsskriftet støtter opp under dette. Et 17-årsmateriale fra Nordlandssykehuset Bodø viser at antallet anestesier og inngrep er stort og økende hos pasienter over 67 år gjennom perioden, og at de over 80 år ikke synes å ha flere komplikasjoner enn de i aldersgruppen 67-79 år (2).

Et viktig korrektiv til denne typen grundig lokal kartlegging er god offisiell nasjonal statistikk fra Norsk pasientregister (3). Det er grunn til å anta at tallene derfra er nokså fullstendige, fordi innrapportering gir grunnlag for utbetaling av innsatsstyrt finansiering. Ifølge registeret utgjør pasienter over 80 år $4,4 \%$ av befolkningen og står for $16 \%$ av ressursbruken i sykehusene. Men den forholdsvis større økning $i$ antall anestesier til pasienter over 67 år som Sommerli \& Nielsen finner i Bodø, kan ikke gjenfinnes i den nasjonale statistikken. Dette kan ha sammenheng med lokale justeringer i kirurgitilbudet til eldre for 8-10 år siden i Nordland, mens Samdata har tall for de siste fem årene nasjonalt.

I alle aldersgrupper gjøres det flere operasjoner nå enn tidligere. Muligheten til å korrigere lidelser og tilstander har økt, kirurgien er blitt mindre invasiv og mer skånsom, anestesien mer styrbar og målrettet. Veksten i dagkirurgi har muliggjort utvidet indikasjonsstilling og flere operasjoner innenfor stramme budsjetter (4). Mens det for eldre tidligere var rigide aldersgrenser for hva som var mulig av forskjellige typer inngrep, tenker man i dag annerledes og individuelt.

Helsen hos eldre er generelt blitt bedre, dessuten kan en individuell vurdering godt tilsi at en frisk 80 -åring er bedre rustet til å tåle et inngrep enn en 40-åring med dårlig helse. Dette gjør diskusjonen knyttet til ekstrabelastning pga. eldrebølgen komplisert: Hva betyr den for antall potensielle pasienter og hva betyr antallet for antatt behov for kirurgi knyttet til de enkelte aldersfaser? Mens gruppen over 67 år er jevnt økende, har ikke antallet eldre over 80 år økt vesentlig de siste 10-20 årene, og man forventer ikke noen økning i Norge før i 2030-årene (5). Det ser ut til at høyere levealder gir en forskyvning i sykdomsbelastningen. Hvis en typisk pasient lever ti år lenger enn tidligere, betyr det ti års utsettelse av den store økningen i behov for helsetjenester som inntreffer mot slutten av livet. En ellers frisk 70-80-åring vil likevel ha et stigende behov for kirurgi med alderen, pga. økt insidens av kreft, hjerte- og karsykdom og slitasje.

Insidensen og faren for komplikasjoner ved anestesi og kirurgi hos eldre er komplisert å beskrive og tallfeste riktig, fordi det er mange reservasjoner og faktorer som kan innvirke. Er indikasjonsstillingen for kirurgi strengere hos eldre? Blir eldre monitorert tettere og med flere ressurser enn yngre? Blir anestesi- og kirurgimetoder tilpasset eldre? Mens Norsk pasientregister kun har data vedrørende komplikasjoner som fører til ekstra diagnoser, tiltak eller innleggelser, vil et anestesiregistreringssystem i utgangspunktet gi mer detaljert informasjon, fordi det her legges opp til å registrere alle typer hen- delser og nestenhendelser. En slik registrering er konsentrert om komplikasjoner knyttet til anestesien og registrering av vitale variabler under og rett etter selve inngrepet, rene kirurgiske problemer og komplikasjoner knyttet til langtidsresultater vil i liten grad inngå. Det er også vist at selv for de perioperative hendelsene er et slikt løpende rutineregistreringssystem lite sensitivt og spesifikt. Mange mindre hendelser blir oversett, og de svært alvorlige er veldig sjeldne (6). Ved Nordlandssykehuset Bodø registrerte man $12-13 \%$ hendelser både i aldersgruppen 67-79 år og i gruppen over 80 år, men dette er ikke ensbetydende med reelle komplikasjoner eller alvorlige hendelser. Mye av registreringen vil gjelde svingninger i blodtrykk og hjertefrekvens, som normalt tåles godt. Anestesi i seg selv er i dag så sikkert at svært få dør av anestesirelaterte årsaker på operasjonsbordet eller i tiden rett etter operasjon (6).

Det kan reises berettigede innvendinger mot generalisering av data fra et enkeltsykehus. Det er også mange metodologiske kommentarer og reservasjoner å knytte til materialet fra Nordlandssykehuset Bodø. De fleste av disse er nevnt av forfatterne selv. Likevel er denne type opptelling og løpende kvalitetssikring viktig for å tenke fremover. Ikke minst skjerper det bevisstheten overfor det økte ressursbehovet vi opplever i dag og som vi vet vil øke ytterligere ved sykehusene fremover. Det er vanskelig å tro at dette kan løses ved å be de ansatte løpe enda fortere samtidig som man kutter og rasjonaliserer. Norge er på ingen måte noen versting når det gjelder overdreven bruk av samfunnets ressurser på helse (7). Tvert imot ligger vi trolig ganske midt på treet når regnestykkene gjøres riktig og korrigeres for ulik registrering av helserelatert pleie landene imellom (8). Med vår velstand og våre vanskelige geografiske forhold bør vi snarere øke innsatsen og kapasiteten ved sykehusene, ikke minst for å kunne ta ordentlig vare på våre eldre.

\section{Johan Ræder}

johan.rader@medisin.uio.no

Johan Ræder (f. 1954) er spesialist i anestesiologi, professor II i anestesiologi ved Universitetet i Oslo og fagansvarlig overlege ved Avdeling for anestesiologi, Oslo universitetssykehus, Ullevål.

Forfatter har fylt ut ICMJE-skjemaet og oppgir ingen interessekonflikter.

\section{Litteratur}

1. Laake JH, Dybwik K, Flaatten HK et al. Impact of the post-World War II generation on intensive care needs in Norway. Acta Anaesthesiol Scand 2010; 54 : 479-84.

2. Sommerli EL, Nielsen EW. Anestesi til eldre ved Nordlandssykehuset Bodø 1993-2009. Tidsskr Nor Legeforen 2012; 132: 2615-7.

3. Huseby BM, red. Samdata spesialisthelsetjenesten 2011. Oslo: Helsedirektoratet, 2012.

4. Ræder J, Nordentoft J. Dagkirurgi og anestesi. Tidsskr Nor Legeforen 2010; 130: $742-6$.

5. Eldre - andelen over 65 år i befolkningen. Folkehelseinstituttet. www.fhi.no/eway/default.aspx?pid=233\&trg=MainLeft 6039\&MainArea 5661= 6039: 0: 15,4576:1:0:0:0:0\&MainLeft 6039=6041:70828:1:6043:8:0:0 (22.11.2012).

6. Fasting S, Gisvold SE. Serious intraoperative problems-a five-year review of 83,844 anesthetics. Can J Anaesth 2002; 49: 545-53.

7. Møinichen-Berstad TL. Helseutgiftene i Norge sammenliknet med andre land. Samfunnsøkonomen 2012, nr. 3: 12-21. 